\title{
Результати опитування лікарів: який НПЗП найпопулярніший?
}

\section{Є.В. Лук'янчук}

Редакція журналу «Український медичний часопис»

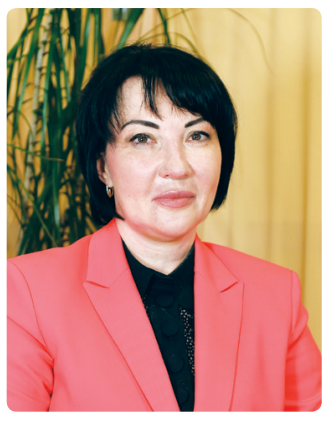

\begin{abstract}
Нестероїдні протизапальні препарати (НПЗП) - одна з найпопулярніших груп ліків, що часто призначають лікарі широкого кола спеціальностей пацієнтам при різних захворюваннях. НПЗП вирізняють добре вивчений механізм дії, доведена ефективність та зручність застосування. В арсеналі лікарів велика кількість НПЗП, і всі вони мають різні ефективність та профіль безпеки. Який НПЗП призначити у тій чи іншій клінічній ситуації? Яким НПЗП надають перевагу колеги? Саме цим питанням була приділена увага в ході онлайн-конференції «Травневі ревмодні», що відбулася 26-27 травня 2021 р. Модераторами заходу виступили Єлизавета Єгудіна, доктор медичних наук, професор, керівник навчального центру Клініки сучасної ревматології, та Семен Тер-Вартаньян, кандидат медичних наук, головний лікар Клініки сучасної ревматології. «Родзинкою» заходу стало оголошення результатів опитування лікарів щодо застосування НПЗП у медичній практиці.
\end{abstract}

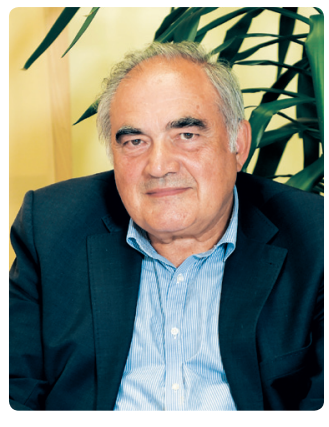

\section{Рейтинг лікарських вподобань: \\ раціональне призначення НПЗП}

Мабуть ні для кого не $\epsilon$ секретом те, що майже всі лікарі призначають НПЗП. Справді, сучасний лікар без цієї групи препаратів, як без рук, що вже казати про ревматологів, які щодня стикаються з необхідністю курації больового синдрому у пацієнтів.

Яким же препаратам надають перевагу лікарі? Тут багато залежить від терміну, на який необхідно призначити знеболювальну терапію. Так, обираючи НПЗП на короткий термін (<14 днів), лікарі різних спеціальностей та ревматологи одностайні у своєму виборі - це має бути диклофенак! I це не дивно, адже диклофенак ефективно усуває біль при широкому спектрі захворювань. Другу позицію займає німесулід, відомий своїм швидким початком анальгезивної дії (рис. 1, 2). У цьому контексті диклофенак $\epsilon$ золотим стандартом знеболювальної та протизапальної терапії, що зумовлює його популярність серед лікарів. Що ж до німесуліду, то він характеризується швидкою всмоктуваністю та швидким настанням ефекту, тому і посідає 2-ге місце.

Рисунок 1 Рейтинг вподобань лікарів різних спеціальностей, які дали відповідь на запитання: якому НПЗП Ви надаєте перевагу при короткостроковому призначенні (до 14 днів)

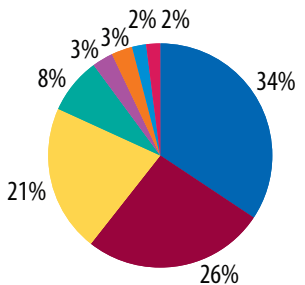
Диклофенак
- Німесулід
Мелоксикам
- Ацеклофенак
- Напроксен
- Целекоксиб
Еторикоксиб
— Жодному не надаю

При призначенні НПЗП на тривалий період (>14 днів) лікарі різних спеціальностей надають перевагу селективним НПЗП, а ревматологи - мелоксикаму, ацеклофенаку та диклофенаку.

Важливим аспектом раціонального вибору НПзП $є$ врахування наявниху пацієнта серцево-судинного або гастроінтестинального ризиків. Так, при підвищеному серцево-судинному ризику лікарі різних спеціальностей надають перевагу мелоксикаму та німесуліду, а серед ревматологів у топ-5 найпопулярніших НПЗП входять напроксен, целекоксиб, мелоксикам, диклофенак та німесулід. При підвищеному гастроінтестинальному ризику лікарі різних спеціальностей надають перевагу мелоксикаму, целекоксибу та німесуліду, а ревматологи - селективним НПЗП.

\section{ДИКЛОБЕРЛ ${ }^{\circledR}$ - диклофенак, якому \\ надали перевагу учасники опитування}

Оскільки диклофенак при короткостроковому призначенні став лідером при опитуванні, як лікарів різних спеціальностей, так і ревматологів, проведено додаткове опитування з приводу того, яким саме препаратам диклофенаку за торговою назвою лікарі надають перевагу.

Відповідно до отриманих результатів серед лікарів різних спеціальностей із величезним відривом (у 40\%!) переміг дИКЛОБЕРЛ («Берлін-Хемі/А. Менаріні Україна ГмбХ»). На думку С. Тер-Вартаньяна, запорукою цього визначного результату стали високий авторитет компанії-виробника та, відповідно, впевненість у якості та хороша переносимість препарату. ДИКЛОБЕРЛ ${ }^{\circledR}$ має зручне дозування і різні форми випуску, що робить зручним його призначення у різних клінічних ситуаціях. $Є$. Єгудіна відмітила, що ДИКЛОБЕРЛ ${ }^{\circledR}$ випускається у формі капсул пролонгованої дії та його можна застосовувати лише 1 раз на добу.

\section{Takeaway notes}

Рейтинг лікарських вподобань відповідно до результатів опитування учасників «Травневі ревмодні» (лікарів різних спеціальностей)

- дИКЛОБЕРл ${ }^{\odot}$ - найпопулярніша торгова марка препаратів диклофенаку.

- Диклофенак — препарат вибору для призначення на строк до 14 днів.

- Німесулід —-2-га позиція у рейтингу НПЗП для призначення на строк до 14 днів.

- Топ-5 НПЗП, за версією ревматологів, при підвищеному серцево-судинному ризику: напроксен, целекоксиб, мелоксикам, диклофенак та німесулід.

- При підвищеному гастроінтестинальному ризику лікарі різних спеціальностей надають перевагу мелоксикаму, целекоксибу та німесуліду. 